\title{
EFFECT OF NITROGEN AND POTASSIUM FERTILISATION ON THE CONTENT OF IONS IN THE SOIL SOLUTION
}

\author{
Barbara Murawska, Ewa Spychaj-Fabisiak \\ Chair of Agricultural Chemistry \\ University of Technology and Life Sciences in Bydgoszez
}

\begin{abstract}
The aim of the present research was to evaluate whether or not, and to what extent, exclusive mineral fertilisation affects the content of water-soluble ions determining the soil salinity. The soil was sampled from the arable layer of a multi-year field experiment carried out in 1974-2007. The research involved differentiated nitrogen fertilisation (factor I, $n=3$ ) and potassium fertilisation (factor II, $n=4$ ). The content of water-soluble ions was defined in water extract, in the soil to water ratio of $1: 5$; cations $\mathrm{K}^{+}, \mathrm{Na}^{+}, \mathrm{Ca}^{2+}$ were determined with the method of emission spectrometry and $\mathrm{Mg}^{2+}$ - with atomic absorption. Anions were analysed with the argentometric $\left(\mathrm{Cl}^{-}\right)$and nephelometric $\left(\mathrm{SO}_{4}{ }^{2-}\right)$ methods. In addition, electrolytic conductivity $(\mathrm{R})$ was tested with the conductometric method, based on which the salt concentration in the solution (C) and the ionic strength (I) were calculated. The present results were statistically verified. The prolonged application of intensive nitrogen and potassium fertilisation (32 years) significantly differentiated the content of cations: $\mathrm{K}^{+}, \mathrm{Na}^{+}, \mathrm{Ca}^{2+}$ and $\mathrm{Mg}^{2+}$ as well as anions: $\mathrm{Cl}^{-}$and $\mathrm{SO}_{4}{ }^{2-}$ in soil solution. The contents of $\mathrm{K}^{+}, \mathrm{Na}^{+}, \mathrm{Ca}^{2+}, \mathrm{Mg}^{2+}$ in the soil solutions differed and fell within the range of (mean value) 0.136-0.507 (0.281) $\mathrm{K}^{+}, 0.398-0.555(0.472) \mathrm{Na}^{+}, 1-2.192(1.350) \mathrm{Ca}^{2+}$ and 0.211- 0.365 (0.272) $\mathrm{Mg}^{2+} \mathrm{mmol}(+) \cdot \mathrm{kg}^{-1}$. The highest nitrogen dose significantly limited the concentration of $\mathrm{SO}_{4}{ }^{2-}$ in the soil solution, while the different doses of potassium did not result in such significant changes in the concentration of the above ions. The content of chlorine ions in the soil solution did not depend significantly on differentiated nitrogen and potassium fertilisation. No effect of the long-term mineral fertilisation on soil salinity was noted.
\end{abstract}

Key words: fertilisation, ions, salt indicator.

dr Barbara Murawska, Chair of Agricultural Chemistry, University of Technology and Life Sciences, ul. Seminaryjna 5, 85-326 Bydgoszcz, Poland, phone (052) 3749006, e-mail: murawska@utp.edu.pl 
WPŁYW NAWOŻENIA AZOTEM I POTASEM NA ZAWARTOŚĆ JONÓW W ROZTWORZE GLEBOWYM

\begin{abstract}
Abstrakt
Celem badań była ocena, czy i na ile wyłączne nawożenie mineralne wpływa na zawartość wodnorozpuszczalnych jonów decydujących o zasoleniu gleby. Próbki gleby pobrano z warstwy ornej wieloletniego doświadczenia polowego, które prowadzono w latach 1974-2007. W badaniach stosowano zróżnicowane nawożenie azotem (I czynnik, $n=3$ ) i potasem (II czynnik, $n=4$ ). Zawartość wodnorozpuszczalnych jonów oznaczono w wyciagu wodnym, stosunek gleby do wody jak 1:5; kationy $\mathrm{K}^{+}, \mathrm{Na}^{+}, \mathrm{Ca}^{2}+$ metoda spektometrii emisyjnej, a $\mathrm{Mg}^{2+}$ metoda absorpcji atomowej, aniony - metoda argentometryczna $\left(\mathrm{Cl}^{-}\right)$oraz nefelometryczna $\left(\mathrm{SO}_{4}{ }^{2-}\right)$. Oznaczono także przewodnictwo elektrolityczne (R) metoda konduktometryczną, na podstawie którego obliczono stężenie soli w roztworze (C) i moc jonowa (I) Wyniki badań opracowano statystycznie. Wieloletnie (32 lata) stosowanie intensywnego nawożenia azotem i potasem istotnie różnicowało zawartości kationów: $\mathrm{K}^{+}, \mathrm{Na}^{+}, \mathrm{Ca}^{2+} \mathrm{i} \mathrm{Mg}^{2+}$ oraz anionów: $\mathrm{Cl}^{-} \mathrm{i} \mathrm{SO}_{4}{ }^{2-} \mathrm{w}$ roztworze glebowym. Zawartość $\mathrm{K}^{+}, \mathrm{Na}^{+}, \mathrm{Ca}^{2+}, \mathrm{Mg}^{2+}$ w roztworze glebowym wynosiła odpowiednio: 0,136-0,507 średnio $(0,281), 0,398-0,555$ średnio $(0,472), 1-2,192$ średnio $(1,350), 0,211-0,365$ średnio $(0,272) \mathrm{mmol}(+) \cdot \mathrm{kg}^{-1}$. Największe dawki azotu istotnie ograniczały koncentrację $\mathrm{SO}_{4}{ }^{2-} \mathrm{w}$ roztworze glebowym, natomiast zróżnicowane dawki potasu nie miały tak znaczącego wpływu. Zawartość jonów chlorowych w roztworze glebowym nie zależała istotnie od różnicowanego nawożenia azotem i potasem. Nie stwierdzono wpływu długoletniego nawożenia mineralnego na zasolenie gleby.
\end{abstract}

Słowa kluczowe: nawożenie, jony, zasolenie.

\title{
INTRODUCTION
}

Soil is a live formation, which shows a specific state of equilibrium between biotic and abiotic processes which determine its fertility. The concentration of respective components in the soil solution varies in time and is conditioned by many factors, both natural and anthropogenic, including brine solutions and industrial wastewater, salts applied for clearing roads from snow and mineral fertilisers (MURAwska 2005, KAsZUBKIEWICZ et al. 2003). These factors can determine soil fertility and quality. They can also condition soil salinity, which manifests chemical degradation of environment (CAMPEBELL et al. 1989, ŁABEтTOWICZ 1995). Soil salinity in seaside soils and soils in the close vicinity of brine has been researched thoroughly (KUCHARSKI 1995, PRACZ 2005). Nonetheless, there is little evidence pertaining to long-term effect of mineral fertilisers, except for natural fertilisation and liming, on the content of cations and anions in soil, which determine its salinity (CAMPEBELL et al. 1989, ŁaвEтOWICZ, RutKowsKa 2001, RutKowska et al. 2009). With that in mind, the present research has been performed to find out whether or not, and if so, to what extent, long-term nitrogen and potassium fertilisation affects the content of water-soluble ions determining the soil salinity. 


\section{MATERIAL AND METHODS}

The research material consisted of soil sampled from the arable layer of long-term field experiment carried out in 1974-2007. Differentiated nitrogen (factor I, $n=3$ ) and potassium (factor II, $n=4$ ) fertilisation was applied (Table 1). Detailed experimental data are provided are reported by MuRAwskA (2005).

Table 1

The application of mineral fertilisers

\begin{tabular}{|c|c|c|c|c|c|c|}
\hline \multicolumn{7}{|c|}{ Fertilisation level (mean/year in $\mathrm{kg} \cdot \mathrm{ha}^{-1}$ ) } \\
\hline \multicolumn{3}{|c|}{$\mathrm{N}$} & \multicolumn{5}{c|}{$\mathrm{K}$} \\
\hline $\mathrm{N}_{1}$ & $\mathrm{~N}_{2}$ & $\mathrm{~N}_{3}$ & $\mathrm{~K}_{0}$ & $\mathrm{~K}_{1}$ & $\mathrm{~K}_{2}$ & $\mathrm{~K}_{3}$ \\
\hline 80 & 160 & 250 & 0 & 50 & 106 & 155 \\
\hline
\end{tabular}

The following determinations were made on the soil samples: content of water-soluble ions in water extract, at the soil-to-water ratio of 1:5; cations $\mathrm{K}^{+}, \mathrm{Na}^{+}, \mathrm{Ca}^{2+}$ using emission spectrometry and $\mathrm{Mg}^{2+}$ with atomic absorption and anions applying the argentometric $\left(\mathrm{Cl}^{-}\right)$and nephelometric $\left(\mathrm{SO}_{4}\right)$ methods. Additionally, electroconductivity $(\mathrm{R})$ with the conductometric method was determined, based on which the salt concentration in the solution (C) and ionic power (I) were calculated from the formulas: $C=640 \cdot R\left(\mathrm{mg} \cdot \mathrm{dm}^{-3}\right)$ and $\mathrm{I}=0.013 \cdot \mathrm{R}\left(\mathrm{mol} \cdot \mathrm{dm}^{-3}\right)$. The results were statistically verified with analysis of variance according to the model compliant with the experimental design, using Tukey's test to evaluate the significance of differences.

\section{RESULTS AND DISCUSSION}

The soil phase is highly sensitive to changes in the chemical composition is the soil solution. These changes are a resultant of numerous factors, including fertilisation (ŁaвEтTowicz, Rutkowska 2001, MurawsKa 2005). Excessively intensive mineral fertilisation increases the content of salts easily soluble in soils. Under Polish climatic conditions, fertiliser salts dissolved by precipitation waters penetrate deep into soil due to the process of migration and increase the degree of mineralization of soil- and groundwater. The present results suggest that the examined nitrogen fertilisation regime significantly determined the content of water-soluble forms of magnesium and sodium, while potassium fertilisation affected the content of potassium, magnesium and calcium (Table 2). They also depended significantly on the interaction of the factors researched. The content of $\mathrm{K}^{+}, \mathrm{Na}^{+}, \mathrm{Ca}^{2+}, \mathrm{Mg}^{2+}$ in the 
Table 2

Content of water-soluble ions in the soil samples $\left(\mathrm{mmol}(+) \cdot \mathrm{kg}^{-1}\right)$

\begin{tabular}{|c|c|c|c|c|c|}
\hline \multicolumn{6}{|c|}{ Potassium } \\
\hline Fertilisation level & $\mathrm{K}_{0}$ & $\mathrm{~K}_{1}$ & $\mathrm{~K}_{2}$ & $\mathrm{~K}_{3}$ & Mean \\
\hline $\mathrm{N}_{1}$ & 0.136 & 0.207 & 0.225 & 0.507 & 0.269 \\
\hline $\mathrm{N}_{2}$ & 0.179 & 0.324 & 0.282 & 0.340 & 0.256 \\
\hline $\mathrm{N}_{3}$ & 0.202 & 0.212 & 0.369 & 0.486 & 0.317 \\
\hline Mean & 0.172 & 0.214 & 0.292 & 0.444 & 0.281 \\
\hline \multicolumn{6}{|c|}{ LSD for I $-\mathrm{ns}, \quad$ II $-0.052, \quad$ IIxI $-0.090, \quad$ IxII -0.089} \\
\hline \multicolumn{6}{|c|}{\begin{tabular}{|c|} 
\\
Magnesium
\end{tabular}} \\
\hline $\mathrm{N}_{1}$ & 0.255 & 0.323 & 0.241 & 0.225 & 0.261 \\
\hline $\mathrm{N}_{2}$ & 0.324 & 0.211 & 0.218 & 0.255 & 0.252 \\
\hline $\mathrm{N}_{3}$ & 0.300 & 0.233 & 0.216 & 0.365 & 0.303 \\
\hline Mean & 0.293 & 0.256 & 0.259 & 0.281 & 0.272 \\
\hline \multicolumn{6}{|c|}{ LSD for I - 0.034, II - 0.039, IIxI 0.067, IxII- 0.062} \\
\hline \multicolumn{6}{|c|}{ Calcium } \\
\hline $\mathrm{N}_{1}$ & 2.192 & 1.275 & 1.000 & 1.017 & 1.371 \\
\hline $\mathrm{N}_{2}$ & 1.542 & 1.050 & 1.033 & 1.173 & 1.200 \\
\hline $\mathrm{N}_{3}$ & 1.400 & 1.617 & 1.500 & 1.400 & 1.479 \\
\hline Mean & 1.711 & 1.314 & 1.178 & 1.197 & 1.350 \\
\hline \multicolumn{6}{|c|}{ LSD for I - n.s., $\quad$ II $-0.409, \quad$ IIxI $0.708, \quad$ IxII -0.665} \\
\hline \multicolumn{6}{|c|}{$\begin{array}{ll} & \text { Sodium } \\
\end{array}$} \\
\hline $\mathrm{N}_{1}$ & 0.441 & 0.455 & 0.398 & 0.477 & 0.443 \\
\hline $\mathrm{N}_{2}$ & 0.505 & 0.497 & 0.405 & 0.501 & 0.477 \\
\hline $\mathrm{N}_{3}$ & 0.467 & 0.437 & 0.555 & 0.528 & 0496 \\
\hline Mean & 0.471 & 0.462 & 0.453 & 0.520 & 0.472 \\
\hline
\end{tabular}

soil solution varied and fell within the range of (the mean): 0.136-0.507 (0.281) $\mathrm{K}^{+}, 0.398-0.555(0.472) \mathrm{Na}^{+}, 1-2.192$ (1.350) $\mathrm{Ca}^{2+}$ and 0.211-0.365 (0.272) $\mathrm{Mg}^{2+} \mathrm{mmol}(+) \cdot \mathrm{kg}^{-1}$.

The content of sulphate ions (VI) in the soil solution was evidently higher than that of cations and the concentration of chlorine ions fell within the concentration range of $\mathrm{K}^{+}, \mathrm{Mg}^{2+}$ and $\mathrm{Na}^{+}$(Table 3). The highest nitrogen dose significantly limited the concentration of $\mathrm{SO}_{4}{ }^{2-}$ in the soil solution, while the potassium doses did not result in such significant changes in the concentration of the above ions. The interaction of nitrogen and potassium 
Table 3

Content of anions in the soil samples $\left(\mathrm{mmol}(+) \cdot \mathrm{kg}^{-1}\right)$

\begin{tabular}{|c|c|c|c|c|c|}
\hline \multicolumn{6}{|c|}{ Sulphate (VI) } \\
\hline $\begin{array}{l}\text { Fertilisation } \\
\text { level }\end{array}$ & $\mathrm{K}_{0}$ & $\mathrm{~K}_{1}$ & $\mathrm{~K}_{2}$ & $\mathrm{~K}_{3}$ & mean \\
\hline $\mathrm{N}_{1}$ & 11.60 & 14.00 & 13.69 & 13.90 & 12.78 \\
\hline $\mathrm{N}_{2}$ & 12.56 & 12.06 & 16.12 & 13.86 & 13.11 \\
\hline $\mathrm{N}_{3}$ & 15.87 & 9.91 & 8.31 & 11.58 & 10.97 \\
\hline Mean & 13.34 & 11.98 & 12.69 & 13.11 & 12.29 \\
\hline \multicolumn{6}{|c|}{ LSD for I - 2.13. II - n.s. IIxI $-4.72 . \quad$ IxII -4.27} \\
\hline \multicolumn{6}{|c|}{ Chlorides } \\
\hline $\begin{array}{c}\text { Fertilisation } \\
\text { level }\end{array}$ & $\mathrm{K}_{0}$ & $\mathrm{~K}_{1}$ & $\mathrm{~K}_{2}$ & $\mathrm{~K}_{3}$ & mean \\
\hline $\mathrm{N}_{1}$ & 0.31 & 0.31 & 0.27 & 0.27 & 0.29 \\
\hline $\mathrm{N}_{2}$ & 0.43 & 0.35 & 0.39 & 0.41 & 0.40 \\
\hline $\mathrm{N}_{3}$ & 0.46 & 0.40 & 0.50 & 0.46 & 0.46 \\
\hline Mean & 0.40 & 0.35 & 0.39 & 0.38 & 0.38 \\
\hline
\end{tabular}

fertilisation significantly differentiated the content of sulphates in the soil solution. This effect was particularly strong when the highest nitrogen dose was applied $\left(\mathrm{N}_{3}\right)$. The highest amount of sulphate (VI) was found in the soil without potassium fertilisation, which - irrespective of its rate - significantly limited their concentration. This effect could have been due to a competitive effect of chlorine ions entering soil with potassium fertilisers as well as an increased uptake of sulphates by plants well supplied with nitrogen.

The content of chlorine ions in the soil solution ranged from 0.27 to $0.50 \mathrm{mmol}(-) \cdot \mathrm{kg}^{-1}$ (on average $0.38 \mathrm{mmol}(-) \cdot \mathrm{kg}^{-1}$ ) and it did not depend significantly on differentiated nitrogen and potassium fertilisation (Table 3).

The percentage share of the analysed cations in the pool increased in the following order: $\mathrm{Mg}^{2+}<\mathrm{K}^{+}<\mathrm{Na}^{+}<\mathrm{Ca}^{2+}$ (Figure 1a). Of the determined anions, sulphates (VI) made up as much as $97 \%$ (Figure $1 b$ ).

The measure of soil salinity is based on the electroconductivity of water-soil extracts, which in the analysed samples was on average $53.3 \mu \mathrm{S} \cdot \mathrm{cm}^{-1}$ (Table 4). It was much lower than the threshold value assumed for saline soils, which is $4 \mathrm{mS} \cdot \mathrm{cm}^{-1}$ (Pracz 2001, Hulisz 2007, Corwim, Lesch, 2005). That parameter can be applied to evaluate other indicators of soil salinity, for example salt concentration in the extract or the ionic power (Table 4), which likewise remained at a very low level in the present research. 


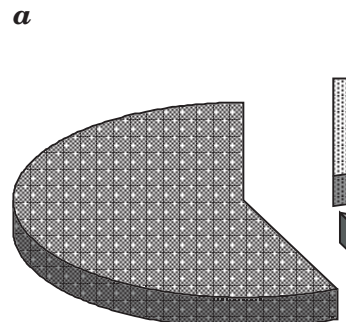

$56.8 \mathrm{Ca}^{2+}$

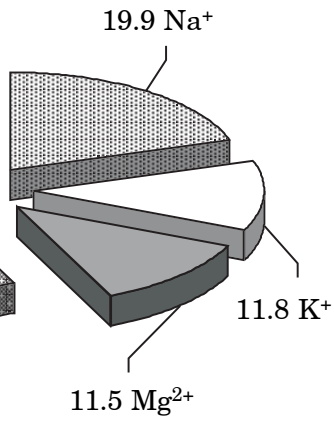

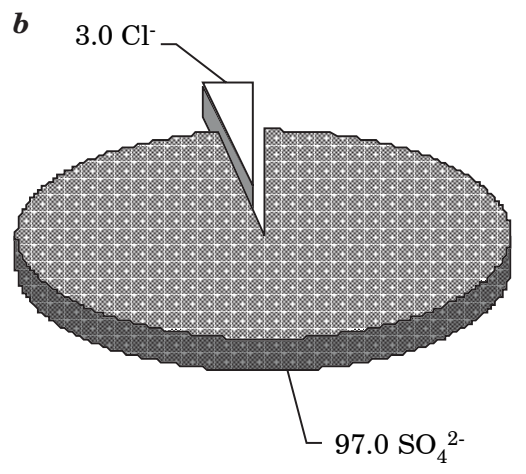

b $\quad 3.0 \mathrm{Cl}^{-}$

Fig. 1. Percentage share of the cations $(a)$ and anions $(b)$

Table 4

Salt indicator

\begin{tabular}{|l|c|c|c|c|}
\hline \multicolumn{2}{|c|}{ Parameter } & Range & Mean & Median \\
\hline Electroconductivity & $\mu \mathrm{S} \cdot \mathrm{cm}^{-1}$ & $35.2-85.90$ & 53.30 & 49.21 \\
\hline Salt concentration & $\mathrm{mg} \cdot \mathrm{dm}^{-3}$ & $20694-55003$ & 34136 & 31495 \\
\hline Ionic power & $\mathrm{M} \cdot \mathrm{dm}^{-3}$ & $0.420-1.117$ & 0.693 & 0.640 \\
\hline
\end{tabular}

\section{CONCLUSIONS}

The present results were statistically verified. The prolonged application of intensive nitrogen and potassium fertilisation (32 years) significantly differentiated the content of cations $\mathrm{K}^{+}, \mathrm{Na}^{+}, \mathrm{Ca}^{2+}, \mathrm{Mg}^{2+}$ and anions $\mathrm{Cl}^{-}, \mathrm{SO}_{4}{ }^{2-}$, although it did not lead to soil salination. It can therefore be stated that salination of the analyse soils was not directly caused by the long-term fertilisation, which under the climatic conditions prevailing in Poland can only increase the degree of mineralization of soil- and groundwater.

\section{REFERENCES}

Campebell D.J., Kinniburgh D.G., Beckett P.H. 1989. The soil solution chemistry of some Oxfordshire soils: temporal and spatial variability. J. Soil Sci., 40: 321-339.

Conwim D. L., Lesch S.M. 2005. Apparent soil electrical conductivity measurements in agriculture. Computers and Electronics in Agriculture, 46: 1-3.

Hulisz P. 2007. Propozycje systematyki gleb zasolonych w Polsce [Suggested taxonomies of saline soils in Poland]. Rocz. Glebozn., 58 (1/2):1-10. (in Polish)

Kaszubkiewicz J., Musią A., Waścińska A. 2003. Zmiany wtaściwości fizycznych i fizykochemicznych wybranych gleb podczas procesów zasalania $i$ odsalania [Modifications in physical and physicochemical properties of some soils during salination and desalination]. Rocz. Glebozn., 54 (3): 5-25. (in Polish) 
KuCHARSKI R. 1995. Dynamika rozprzestrzeniania się zasolenia i zanieczyszczeń wód podziemnych na obszarze Ciechocinka [Dynamics of spreading salination and groundwater pollution in Ciechocinek]. Prz. Geol., 43 (6): 483-486. (in Polish)

ŁABĘTOWICZ J., 1995. Sktad chemiczny roztworu glebowego $w$ zróżnicowanych warunkach glebowych $i$ nawozowych. [Chemical composition of soil solution under different soil land fertilisation conditions]. SGGW Warszawa, pr. habil., 103 ss. (in Polish)

ŁABĘTOwicz J., RutKowsKa B. 2003. Czynniki ksztattujace stężenie potasu w roztworze glebowym gleb uzytkowanych rolniczo $w$ Polsce [Factors shaping the concentration of potassium in soil solution of agricultural soils in Poland]. Zesz. Probl. Post. Nauk Rol., 480: 95-102. (in Polish)

Murawska B. 2005. Wptyw różnych systemów nawożenia na mobilność potasu $w$ glebie $i$ jego bilans. [Effect of different fertilization systems on mobility of potassium in soil and potassium balance] Nawozy i Nawożenie. 3: 189-205. (in Polish)

Pracz J. 2005 Organiczne gleby stone występujace $w$ rejonie Zatoki Puckiej [Organically saline soils in the environs of the Bay of Puck]. Rocz. Glebozn., 56 (3/4): 89-99. (in Polish)

Rutkowska B., Szulc W., Łabętowicz J. 2009. Influence of soil fertilisation on concentration of microelements in soil solution of sandy soil. J. Elementol., 14(2): 349-355. 
